\title{
ANALISIS KESESUAIAN LAHAN UNTUK TANAMAN JERUK DI KELURAHAN PEGAGAN JULU I KECAMATAN SUMBUL KABUPATEN DAIRI
}

\author{
Edi Valdo Sipayung, Anik Juli Dwi Astuti \\ Jurusan Pendidikan Geografi, Fakultas IImu Sosial, Universitas Negeri Medan \\ JI. Willem Iskandar Pasar V, 20221, Medan, Indonesia \\ Email:anikjuli83@gmail.com
}

\begin{abstract}
Abstrak
Tujuan penelitian ini untuk mengetahui: 1) Karakteristik lahan yang dilihat dari suhu, ketersediaan air, kondisi perakaran, daya menahan hara, ketersediaan unsur hara dan topografi untuk lahan jeruk di Kelurahan Pegagan Julu I Kecamatan Sumbul Kabupaten Dairi. 2) Kesesuaian lahan untuk tanaman jeruk dilihat dari karakteristik lahan (suhu, ketersediaan air, kondisi perakaran, daya menahan hara, ketersediaan unsur hara dan topografi) di Kelurahan Pegagan Julu I Kecamatan Sumbul Kabupaten Dairi. Penelitian ini dilakukan di Kelurahan Pegagan Julu I Kecamatan Sumbul Kabupaten Dairi tahun 2017. Populasi dalam penelitian ini ialah seluruh lahan kering di Kelurahan Pegagan Julu I seluas 146 Ha. Sampel ditentukan secara Stratified Random Sampling berdasarkan kelas kemiringan lereng daerah penelitian. Teknik pengumpulan data yang dilakukan ialah observasi, pengukuran dan studi dokumenter. Teknik analisis yang digunakan adalah teknik analisis deskriptif kualitatif. Hasil penelitian menunjukkan bahwa: 1) Karakteristik lahan di Kelurahan Pegagan Julu I cukup baik untuk peruntukan tanaman jeruk. Hal ini didukung oleh rata-rata suhu harian sebesar 21,50 C dan curah hujan tahunan sebesar $1.794 \mathrm{~mm} /$ tahun yang baik untuk tanaman jeruk. Beberapa karakteristik lahan yang lain juga mendukung tumbuhnya tanaman jeruk karena memiliki drainase yang agak baik, tekstur lempung berpasir, kedalaman tanah yang dalam sekitar 78-94 cm, KTK liat yang cukup sebesar 8,37-11,34, $\mathrm{PH} \mathrm{H}_{2} \mathrm{O}$ yang normal antara 5,676,12, $\mathrm{P}_{2} \mathrm{O}_{5}$ sebesar 10,24-13,09 ppm dan tidak terdapatnya batuan di permukaan serta singkapan batuan. Karakteristik yang menghambat tumbuhnya tanaman jeruk ialah ketersediaan N-Total yang rendah dan kemiringan lereng yang terjal dengan persentase luas lahan sebesar 2\% dari keseluruhan lahan di kelurahan tersebut. 2) Kelurahan Pegagan Julu I berada pada kelas kesesuaian lahan S2sr. Lahan yang memiliki pembatas paling banyak adalah satuan lahan IV dan $V$ dengan persentase luas lahan sebesar 5\% dari keseluruhan lahan dan faktor pembatasnya ialah ketersediaan N-Total yang berada pada kelas $S 3$ dan Kemiringan lereng yang berada pada kelas $N$. Sedangkan lahan yang memiliki pembatas paling sedikit adalah satuan lahan I, II dan III dengan persentase luas sebesar 95\% dari keseluruhan lahan. Faktor pembatas ringan pada satuan lahan ini yaitu KTK, N-Total, $P_{2} \mathrm{O}_{5}$ dan kemiringan lereng yang masing berada pada kelas S2. Drainase, tekstur, $\mathrm{pH}$, batuan permukaan dan singkapan batuan menjadi faktor pendukung di satuan lahan ini karena masing-masing berada pada kelas $S 1$.
\end{abstract}

Kata kunci: Kesesuaian Lahan, Tanaman Jeruk

\section{PENDAHULUAN}

Indonesia sebagai negara agraris memiliki potensi pertanian yang cukup besar yang dapat berkontribusi terhadap pembangunan dan ekonomi nasional (Siswanto, 2006). Penduduk di Indonesia sebagian besar juga menggantungkan hidupnya dari sektor pertanian (Simarmata, 2015). Sektor pertanian terdiri dari peternakan, perikanan dan kehutanan, memiliki potensi yang sangat besar dalam menyerap tenaga kerja di Indonesia. Sektor 
pertanian menyerap $33,9 \%$ dari total angkatan kerja di Indonesia dan menyumbang $14,7 \%$ bagi GNP Indonesia (BPS, 2014). Fakta-fakta tersebut menguatkan pertanian sebagai megasektor yang sangat vital bagi perekonomian Indonesia.

Seiring dengan perkembangan globalisasi dan meningkatnya arus impor barang konsumsi, Indonesia masih menempatkan sektor pertanian dan perkebunan sebagai komoditi unggulan di dunia internasional (Sianturi, 2017). Salah satu komoditas unggulan tersebut adalah jeruk. Namun dalam pemenuhan konsumsi dalam negeri, Indonesia ternyata harus mengimpor buah jeruk dari negara Brazil, China, Amerika, Spanyol sebesar 91.802 per tahun (BPS, 2014).

Tanaman jeruk (Citrus Sp) merupakan tanaman penghasil vitamin $C$ yang tinggi dibandingkan dengan beberapa buah lainnya dan dapat dijadikan sebagai tanaman olahan. Sebagian negara telah diproduksi minyak dari kulit dan biji jeruk, gula tetes, alkohol dan pectin dari buah jeruk yang terbuang. Minyak kulit jeruk dapat dipakai untuk membuat minyak wangi dan sabun wangi, esens minuman dan untuk campuran kue. Beberapa jenis jeruk juga dipakai untuk obat tradisional penurun panas, pereda nyeri saluran pernafasan bagian atas dan penyembuh radang mata (Kartasapoetra, 1988).

Keadaan iklim sangat berpengaruh terhadap pertumbuhan dan produksi tanaman jeruk. Jeruk dapat tumbuh dengan baik pada daerah antara $40^{\circ} \mathrm{LU}-40^{\circ} \mathrm{LS}$. Indonesia yang terletak pada $60 \mathrm{LU}-110 \mathrm{LS}$, sebenarnya merupakan daerah yang sangat potensial untuk budidaya tanaman jeruk. Curah hujan optimum rata-rata yang diperlukan tanaman jeruk adalah 1000 sampai $2000 \mathrm{~mm} /$ tahun merata sepanjang tahun, dan perlu 6-9 bulan basah (musim hujan) untuk pembentukan bunga dan buah serta supaya tanahnya tetap lembab. Temperatur optimal antara 25-300 C dengan kelembaban optimum sekitar 70-80\% (Fauzi, 2012).

Kelurahan Pegagan Julu I merupakan salah satu kelurahan dari 19 kelurahan di Kecamatan Sumbul Kabupaten Dairi yang sebagian besar penduduknya menggantungkan hidup pada sektor pertanian. Dilihat dari letak astronomisnya, Kelurahan pegagan Julu I terletak pada posisi
20 30' LU - 20 32' LU dan 980 30' BT - 980 $34^{\prime} \mathrm{BT}$, memiliki luas $3,78 \mathrm{Km} 2(378 \mathrm{Ha})$. Kelurahan ini memiliki banyak potensi dibidang pertanian dengan luas lahan pertanian sebesar $247 \mathrm{Ha}$ atau sekitar 78,30 $\%$ dari keseluruhan luas wilayahnya dan luas lahan untuk tanaman jeruk sebesar 105,42 Ha (Data Monografi Kelurahan Pegagan Julu I, 2015).

Sektor perkebunan di Kelurahan Pegagan Julu I Kecamatan Sumbul Kabupaten Dairi merupakan perkebunan yang didominasi oleh lahan perkebunan rakyat dengan komoditi kopi dan sayur sayuran. Perkembangan tingkat kebutuhan masyarakat terhadap kepentingan ekonomi mengubah pola pikir masyarakat dalam pengembangan pertanian terutama dibidang agribisnis. Mayoritas masyarakat di Kelurahan Pegagan Julu I bercocok tanam tanaman kopi, namun dewasa ini banyak masyarakat di kelurahan ini yang melirik dan beralih ke pertanian tanaman jeruk.

Hasil wawancara awal penulis terhadap 15 warga yang merupakan petani tanaman kopi di Kelurahan Pegagan Julu I, mereka berpendapat bahwa berkurangnya penghasilan masyarakat disektor pertanian kopi dipengaruhi oleh hasil produksi tanaman kopi yang dari tahun ke tahun semakin berkurang, sehingga masyarakat di Kelurahan Pegagan Julu I yang dahulunya bercocok tanam kopi mulai berpindah ke bercocok tanam jeruk. Sebagian petani juga berpendapat bahwa pengalihan pertanian tanaman kopi ke tanaman jeruk, dipengaruhi oleh informasi adanya penurunan suplai buah jeruk dari Kabupaten Karo ke pasar lokal maupun nasional akibat bencana meletusnya Gunung Sinabung tahun 2013. Untuk itu, petani berusaha memanfaatkan peluang tersebut untuk meningkatkan kondisi perekonomian mereka dengan menanam tanaman jeruk.

Umumnya petani di Kelurahan Pegagan Julu I belum mengetahui tingkat kesesuaian lahan daerah tersebut apabila ditanami tanaman jeruk. Padahal penting untuk mengetahui kesesuaian lahan untuk ditanami dengan tanaman tertentu sehingga nantinya dapat memberikan hasil yang optimal. Untuk mengetahui kondisi lahan yang sesuai untuk tanaman jeruk maka perlu dilakukan 
penelitian mengenai analisis kesesuaian lahan di lokasi tersebut.

\section{METODE PENELITIAN}

Penelitian ini dilakukan di Kelurahan Pegagan Julu I Kecamatan Sumbul Kabupaten Dairi dengan titik koordinat $2^{\circ} 30^{\prime}$ LU - 20 32' LU dan 98 30' BT - $98^{\circ}$ 34' BT. Adapun alasan memilih lokasi tersebut adalah dengan pertimbangan terjadinya pengalihan pertanian tanaman kopi ke tanaman jeruk di Kelurahan Pegagan Julu I Kecamatan Sumbul dan sebagian besar petani belum mengetahui kesesuaian lahan untuk tanaman jeruk di Kelurahan Pegagan Julu I Kecamatan Sumbul. Populasi dalam penelitian ini adalah seluruh lahan perkebunan masyarakat di Kelurahan Pegagan Julu I Kecamatan Sumbul Kabupaten Dairi. Sampel dalam penelitian ini sebanyak 5 (lima) titik sampel yang ditentukan dengan teknik Stratified Random Sampling. Penentuan titik sampel didasarkan pada kelas kemiringan lereng dengan menggunakan peta lereng Kelurahan Pegagan Julu I Kecamatan Sumbul. Berikut titik lokasi pengambilan sampel yang disajikan pada Tabel 1 .

Tabel 1. Titik Lokasi Pengambilan Sampel

\begin{tabular}{|c|c|c|c|c|}
\hline \multirow{2}{*}{ No } & \multirow{2}{*}{ Lokasi } & \multicolumn{2}{|c|}{ Koordinat } & \multirow{2}{*}{ Kemiringan } \\
\hline & & LU & BT & \\
\hline 1 & Titik I & $02^{\circ} 44^{\prime} 19,35^{\prime \prime}$ & $98^{\circ} 24^{\prime} 18,90^{\prime \prime}$ & $4 \%$ \\
\hline 2 & Titik II & $02^{\circ} 45^{\prime} 10,24^{\prime \prime}$ & $98^{\circ} 25^{\prime} 41,49^{\prime \prime}$ & $9 \%$ \\
\hline 3 & Titik III & $02^{\circ} 43^{\prime} 48,28^{\prime \prime}$ & $98^{\circ} 23^{\prime} 23,97^{\prime \prime}$ & $18 \%$ \\
\hline 4 & Titik IV & $02^{\circ} 44^{\prime} 16,32^{\prime \prime}$ & $98^{\circ} 23^{\prime} 30,18^{\prime \prime}$ & $28 \%$ \\
\hline 5 & Titik V & $02^{\circ} 44^{\prime} 22,37^{\prime \prime}$ & $98^{\circ} 23^{\prime} 20,02 ”$ & $43 \%$ \\
\hline
\end{tabular}

Alat dan bahan yang digunakan dalam penelitian ini sebagai berikut:

1. Alat

a. Kamera digital digunakan untuk mengambil gambar atau foto sebagai dokumentasi penelitian.

b. Alat tulis, digunakan untuk mencatat hasil pengukuran di lapangan atau pencatatan hal-hal yang diperlukan pada saat di lapangan.

c. Lembar observasi, digunakan sebagai pedoman dalam mengobservasi objek yang diteliti berisi kriteria yang telah ditentukan.

d. Sekop/cangkul, digunakan untuk menggali tanah dalam mengambil sampel tanah.

e. Bor tanah, digunakan untuk mengebor tanah.

f. GPS (Global Positioning System), digunakan untuk menentukan titik koordinat lokasi penelitian.

g. Plastik sample, digunakan sebagai wadah sampel yang akan diuji di laboratorium

h. Meteran, digunakan untuk mengukur kedalaman tanah

i. Abney level meteran, digunakan untuk mengukur kemiringan lereng

2. Bahan a. Sampel tanah

b. Peta jenis tanah

c. Data curah hujan dan temperatur

Teknik analisis data dalam penelitian ini adalah dengan menggunakan teknik analisis data deskriptif, yaitu data yang diperoleh dari lapangan ditulis dalam bentuk uraian atau laporan terperinci. Analisis kesesuaian lahan dilakukan dengan menggunakan metode Matching yaitu mencocokkan data hasil dari pengukuran secara langsung di lapangan maupun hasil uji laboratorium dengan persyaratan tumbuh tanaman jeruk.

\section{HASIL DAN PEMBAHASAN}

Pertanian merupakan kegiatan utama yang diusahakan di Kelurahan Pegagan Julu I, kondisi lahan yang didominasi lahan kering membuat daerah ini banyak diusahakan untuk pertanian tegalan serta perkebunan. Kondisi lahan yang sesuai untuk tanaman jeruk dapat dilihat dengan mengambil sampel pada lahan kering baik yang telah diusahakan untuk tanaman bukan jeruk, lahan kosong serta lahan yang sedang diusahakan tanaman jeruk. Untuk mengetahui kondisi lahan di kelurahan 
ini, maka perlu diketahui kelas kesesuaian lahan melalui data karakteristik lahan.

\section{Karakteristik Lahan}

Kesesuaian lahan dapat ditentukan berdasarkan kualitas lahan, dari kualitas lahan akan diketahui pembatas suatu lahan. Berikut karakteristik lahan yang dijadikan sebagai indikator kesesuaian lahan dalam penelitian ini.

a. Regim Temperatur (Suhu Udara)

Keberadaan suhu udara suatu daerah sangat berpengaruh pada jenis tumbuhan yang tumbuh pada daerah tersebut.
Berdasarkan data monografi Kelurahan Pegagan Julu I, desa ini memiliki suhu $21,5^{\circ} \mathrm{C}$.

b. Ketersediaan Air (Curah Hujan)

Data iklim yang diperoleh dari kantor BMKG Sampali Sumatera Utara selama 10 Tahun Terakhir yaitu data curah hujan Kecamatan Sumbul yang dianggap dapat mewakili data iklim di Kelurahan Pegagan Julu I. Curah hujan di Kelurahan Pegagan Julu I yaitu 1.794 millimeter. Berdasarkan data curah hujan pada Tabel 2 dapat diketahui jumlah bulan basah dan bulan kering pada bulan yang dapat digunakan untuk mengetahui musim tanam pada tanaman jeruk.

Tabel 2. Jumlah Bulan Basah dan Bulan Kering Berdasarkan Musim Tanam Jeruk.

\begin{tabular}{|c|c|c|c|c|c|c|c|c|c|c|c|c|c|c|}
\hline \multirow{2}{*}{ No } & \multirow{2}{*}{ Jenis Bulan } & \multicolumn{12}{|c|}{ Bulan } & \multirow{2}{*}{ Jumlah } \\
\hline & & 1 & 2 & 3 & 4 & 5 & 6 & 7 & 8 & 9 & 10 & 11 & 12 & \\
\hline 1 & Bulan Basah & 8 & 4 & 8 & 9 & 7 & 2 & 5 & 9 & 8 & 8 & 10 & 10 & 85 \\
\hline 2 & Bulan Lembab & 1 & 5 & 0 & 0 & 2 & 5 & 2 & 0 & 2 & 0 & 0 & 0 & 19 \\
\hline 3 & Bulan Kering & 1 & 2 & 2 & 1 & 2 & 3 & 3 & 1 & 0 & 2 & 0 & 0 & 16 \\
\hline
\end{tabular}

Sumber: Data olahan, 2017

c. Kondisi Perakaran (f)

1) Drainase Tanah

Drainase merupakan keadaan dan cara air (Excess Water) keluar dari tanah atau kemampuan tanah melalukan air dan udara.
Kondisi drainase tanah sangat berpengaruh terhadap baik tidaknya tanaman jeruk tumbuh. Keadaan drainase pada titik lokasi sampel penelitian disajikan pada Tabel 3.

\section{Tabel 3. Kondisi Drainase Tanah di Kelurahan Pegagan Julu I Tahun 2017}

\begin{tabular}{|c|c|c|c|}
\hline No & $\begin{array}{l}\text { Lokasi } \\
\text { Sampel }\end{array}$ & Drainase & Keterangan \\
\hline 1 & I & $\begin{array}{l}\text { d3 (Agak } \\
\text { Buruk) }\end{array}$ & $\begin{array}{l}\text { lapisan atas tanah beraerasi baik, tidak terdapat bercak-bercak berwarna } \\
\text { kuning, kelabu atau coklat. Bercak-bercak terdapat pada seluruh lapisan } \\
\text { bagian bawah (sekitar } 40 \mathrm{~cm} \text { dari permukaan tanah) }\end{array}$ \\
\hline 2 & II & d1 (Baik) & $\begin{array}{l}\text { tanah memiliki peredaran udara (aerasi) yang baik. Seluruh profil tanah dari } \\
\text { atas sampai ke bawah }>150 \mathrm{~cm} \text {, berwarna terang yang seragam dan tidak } \\
\text { terdapat keratan } \\
\text { (bercak-bercak kuning, coklat atau kelabu) }\end{array}$ \\
\hline 3 & III & $\begin{array}{l}\text { d3 } \\
\text { (Agak } \\
\text { Buruk) }\end{array}$ & $\begin{array}{l}\text { lapisan atas tanah beraerasi baik, tidak terdapat bercak-bercak berwarna } \\
\text { kuning, kelabu atau coklat. Bercak-bercak terdapat pada seluruh lapisan } \\
\text { bagian bawah (sekitar } 40 \mathrm{~cm} \text { dari permukaan tanah) }\end{array}$ \\
\hline 4 & IV & $\begin{array}{l}\text { d3 } \\
\text { (Agak } \\
\text { Buruk) }\end{array}$ & $\begin{array}{l}\text { lapisan atas tanah beraerasi baik, tidak terdapat bercak-bercak berwarna } \\
\text { kuning, kelabu atau coklat. Bercak-bercak terdapat pada seluruh lapisan } \\
\text { bagian bawah (sekitar } 40 \mathrm{~cm} \text { dari permukaan tanah) }\end{array}$ \\
\hline 5 & V & $\begin{array}{l}\mathrm{d} 2 \\
\text { (Agak } \\
\text { Baik) }\end{array}$ & $\begin{array}{l}\text { tanah beraerasi baik di daerah perakaran. Tidak terdapat bercak-bercak } \\
\text { berwarna kuning, coklat atau kelabu pada lapisan atas dan bagian lapisan } \\
\text { bawah (sampai sekitar } 60 \mathrm{~cm} \text { dari permukaan tanah) }\end{array}$ \\
\hline
\end{tabular}

Sumber: Hasil Pengamatan di Lapangan, 2017 
Sesuai dengan Tabel 3 dapat diketahui bahwa sampel pada lokasi pengamatan I, III, dan IV memiliki kondisi drainase Agak Buruk. Hal ini diketahui dari pengamatan tanah dengan terdapatnya bercak berwarna kuning, kelabu atau coklat pada tanah. Sedangkan pada sampel pada lokasi I dan II memiliki kondisi drainase yang baik dan agak baik. Tanah sampel I memiliki peredaran udara yang baik dan memiliki warna seragam. Tanah sampel II memiliki aerasi yang baik di daerah perakaran dan tidak terdapat bercak-bercak kuning, coklat dan kelabu.

\section{2) Tekstur Tanah}

Tekstur tanah merupakan salah satu faktor penting yang mempengaruhi kapasitas tanah dalam menahan air dan permeabilitas tanah. Berikut hasil analisis laboratorium mengenai kondisi tekstur tanah di Kelurahan Pegagan Julu I yang diambil dari beberapa titik sampel yang disajikan pada Tabel 4.

Tabel 4. Kondisi Tekstur Tanah di Kelurahan Pegagan Julu I Tahun 2017

\begin{tabular}{cccccc}
\hline \multirow{2}{*}{ No } & \multirow{2}{*}{ Lokasi Sampel } & \multicolumn{3}{c}{ Parameter } & Tekstur \\
\cline { 3 - 5 } & & Pasir (\%) & Debu (\%) & Liat (\%) & Lempung Berpasir \\
\hline 1 & I & 77 & 16 & 6 & Lempung Berpasir \\
2 & II & 55 & 34 & 49 & Lempung Berpasir \\
3 & III & 55 & 34 & 10 & Lempung Berdebu \\
4 & IV & 25 & 58 & 16 & Lempung \\
5 & V & 45 & 38 & 16 & \multicolumn{3}{c}{ Sumber: Hasil Uji Laboratorium, 2017 }
\end{tabular}

Sesuai dengan Tabel 4 dapat dilihat bahwa pada dari 5 lokasi Sampel tekstur tanah lebih didominasi dengan lempung berpasir yang terdapat pada lokasi sampel I, II dan III. Tekstur lempung berdebu didapati pada lokasi sampel IV dengan persentase pasir 25\%, debu $58 \%$ dan liat $16 \%$. Tekstur lempung terdapat pada lokasi sampel $V$ dengan persentase pasir $45 \%$, debu $38 \%$ dan liat $16 \%$.
3) Kedalaman Tanah

Kedalaman tanah merupakan dalamnya tanah yang efektif bagi pertumbuhan akar tanaman, yaitu sampai pada lapisan yang tidak dapat ditembus oleh akar tanaman. Dari hasil pengamatan di lapangan didapat tingkat kedalaman tanah yang berbeda pada beberapa titik sampel yang disajikan pada Tabel 5.

Tabel 5. Tingkat Kedalaman Efektif Tanah di Kelurahan Pegagan Julu I Tahun 2017

\begin{tabular}{cccc}
\hline No & Lokasi Sampel & Kedalaman $(\mathrm{cm})$ & Kriteria \\
\hline 1 & I & 80 & Sedang \\
2 & II & 78 & Sedang \\
3 & III & 83 & Sedang \\
4 & IV & 87 & Sedang \\
5 & V & 94 & Dalam
\end{tabular}

Berdasarkan Tabel 24 dapat diketahui kedalaman tanah di setiap lokasi pengamatan yaitu pada lokasi I, II, III, IV dan $V$ memiliki tingkat kedalaman di atas $60 \mathrm{~cm}$ dengan kriteria sedang dan dalam. Semakin dalam suatu tanah akan semakin mudah akar tanaman berkembang dengan baik. Pengamatan kedalaman efektif tanah dilakukan dengan membuat irisan profil tanah. 


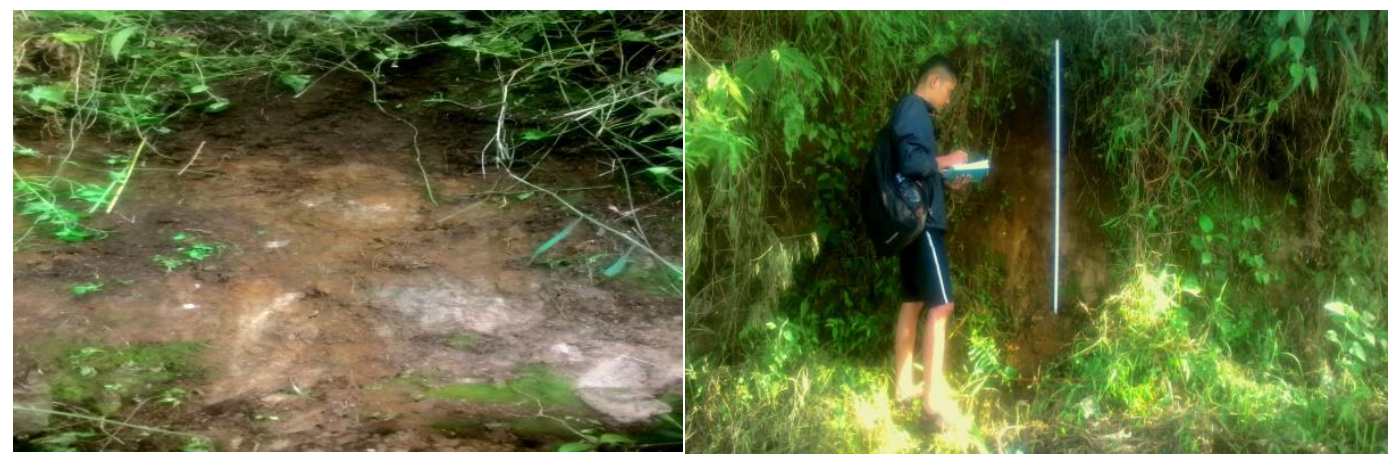

Gambar 1. Pengukuran Kedalaman Tanah dengan Membuat Profil Tanah

Gambar 1 menunjukkan pengamatan ke dalam efektif tanah pada lokasi penelitian dengan membuat profil tanah. Pengukuran ini menunjukkan masih terdapatnya akar tanaman yang menyebar pada kedalaman 75 $95 \mathrm{~cm}$.

d. Daya Menahan Unsur Hara (f)

1) $\mathrm{pH}$ Tanah

Keasaman atau kealkalian tanah menunjukkan konsentrasi ion Hidrogen $\left(\mathrm{H}^{+}\right)$ dalam tanah. Semakin banyak kandungan $\mathrm{H}^{+}$ dalam tanah maka semakin masam tanah tersebut atau nilai $\mathrm{pH}$ tanah semakin rendah, selain kandungan $\mathrm{H}^{+}$terdapat juga kandungan $\mathrm{OH}^{-}$pada tanah yang jumlahnya berbanding terbalik dengan $\mathrm{H}^{+}$. Tinggi rendahnya nilai $\mathrm{pH}$ dapat ditentukan oleh berbagai faktor yang menyebabkan nilai $\mathrm{pH}$ pada setiap lahan pun berbeda-beda. Berikut nilai $\mathrm{pH}$ tanah di Kelurahan Pegagan Julu I yang disajikan pada Tabel 6.

Tabel 6. Kondisi pH pada Sampel Tanah di Kelurahan Pegagan Julu I Tahun 2017

\begin{tabular}{cccc}
\hline No & Lokasi Sampel & Kadar & Kriteria \\
\hline 1 & I & 5,67 & Sedikit Masam \\
2 & II & 5,84 & Sedikit Masam \\
3 & III & 6,12 & Kurang Masam \\
4 & IV & 5,97 & Sedikit Masam \\
5 & V & 5,76 & Sedikit Masam \\
\hline
\end{tabular}

Sumber: Hasil Uji Laboratorium, 2017

Berdasarkan Tabel 6 dapat dilihat kondisi pH tanah pada seluruh lokasi sampel didominasi kriteria sedikit masam yang terdapat pada Lokasi sampel I, II, IV dan V. Persentase pH yang kurang masam hanya terdapat pada lokasi sampel III. Kondisi data tersebut dapat menggambarkan bahwa $\mathrm{pH}$ di beberapa titik masih tergolong pada tingkat keasaman yang sedang.

2) KTK

Kapasitas Tukar Kation (KTK) merupakan jumlah muatan negatif tanah baik yang bersumber dari permukaan koloid anorganik (liat) maupun koloid organik (humus) yang merupakan situs pertukaran kation-kation. Keberadaan KTK pada tanah sama halnya dengan $\mathrm{pH}$ tanah yaitu sangat erat hubungannya dengan kesuburan tanah. Kebutuhan akan KTK berbeda-beda pada setiap penggunaan tanaman tertentu. Begitu juga dengan tanaman jeruk. Berikut disajikan pada Tabel 7 jumlah KTK pada setiap sampel di lokasi penelitian. 
Tabel 7. Kondisi KTK pada Sampel Tanah di Kelurahan Pegagan Julu I Tahun 2017

\begin{tabular}{cccc}
\hline No & Lokasi Sampel & Kriteria (me/100 gram) & Kelas \\
\hline 1 & I & 9,12 & Rendah \\
2 & II & 11,34 & Rendah \\
3 & III & 8,37 & Rendah \\
4 & IV & 10,29 & Rendah \\
5 & V & 10,76 & Rendah \\
\hline & & & Sumber: Hasil Uji Laboratorium, 2017
\end{tabular}

Berdasarkan hasil analisis KTK pada Tabel 7 menunjukkan perbedaan Persentase KTK pada setiap sampel. Pada sampel I sebanyak 9,12, pada sampel II sebanyak 11,34, pada sampel III sebanyak 8,37 , pada sampel IV sebanyak 10,29 dan pada sampel $V$ sebanyak 10,76. Dari data tersebut dapat disimpulkan bahwa persentase KTK pada seluruh sebaran titik sampel di Kelurahan Pegagan Julu I memiliki kriteria Rendah.

e. Ketersediaan Unsur Hara (f)

1) N-Total

Unsur nitrogen merupakan unsur hara makro esensial yang sangat dibutuhkan oleh tanaman. Keberadaan unsur ini mampu menyuburkan tanaman karena akan membentuk protein. Daun-daunan dan berbagai persenyawaan organik lainnya dan hasil yang diperoleh oleh tanaman jeruk ialah berupa buah, namun dalam proses pertumbuhan daun sangat berpengaruh penting sebagai tempat berlangsungnya proses pembentukan zat makanan bagi tanaman yaitu proses fotosintetis. Berdasarkan hasil analisis Laboratorium Riset dan Teknologi Tanah Universitas Sumatera Utara kadar Unsur $\mathrm{N}$ pada tanah di Kelurahan Pegagan Julu I pada kelima titik sampel disajikan pada Tabel 8.

Tabel 27. Kadar Unsur N-Total pada Sampel Tanah di Kelurahan Pegagan Julu I Tahun 2017

\begin{tabular}{cccc}
\hline No & Lokasi Sampel & Kadar (\%) & Kelas \\
\hline 1 & I & 0,13 & Rendah \\
2 & II & 0,15 & Rendah \\
3 & III & 0,15 & Rendah \\
4 & IV & 0,14 & Rendah \\
5 & V & 0,09 & Sangat Rendah \\
\hline
\end{tabular}

Berdasarkan Tabel 8 kadar setiap unsur N-Total pada setiap sampel tanah di Kelurahan Pegagan Julu I adalah yang berada pada kelas Rendah dan Sangat Rendah.

\section{2) $\mathrm{P}_{2} \mathrm{O}_{5}$ Tersedia}

Unsur fosfor juga merupakan salah satu unsur yang sangat dibutuhkan oleh tanaman jeruk. Dari hasil uji Laboratorium Riset dan Teknologi Tanah Universitas Sumatera Utara, diperoleh data tentang kadar unsur P pada lahan di Kelurahan Pegagan Julu I yang diambil dari 5 titik sampel yang disajikan pada Tabel 9.

Tabel 9. Kadar Unsur $\mathrm{P}_{2} \mathrm{O}_{5}$ Tersedia pada Sampel Tanah di Kelurahan Pegagan Julu I Tahun 2017

\begin{tabular}{cccc}
\hline No & Lokasi Sampel & Kadar $(\mathrm{ppm})$ & Kelas \\
\hline 1 & I & 10,37 & Sedang \\
2 & II & 12,10 & Sedang \\
3 & III & 10,54 & Sedang \\
4 & IV & 13,09 & Sedang \\
5 & V & 10,24 & Sedang
\end{tabular}

Sumber: Hasil Uji Laboratorium, 2017 
Berdasarkan Tabel 9 diketahui bahwa pada seluruh sebaran titik sampel unsur $\mathrm{P}_{2} \mathrm{O}_{5}$ memiliki kadar yang relatif sama dengan kategori sedang. Kadar $\mathrm{P}_{2} \mathrm{O}_{5}$ terendah berada pada lokasi $\mathrm{V}$ sebesar $10,24 \mathrm{ppm}$ dengan kategori sedang. Kadar $\mathrm{P}_{2} \mathrm{O}_{5}$ tertinggi pada lokasi IV sebesar 13,09 dengan kategori sedang. f. Topografi (s)

1) Kelas Lereng

Kemiringan lereng dinyatakan dalam derajat atau persen. Kemiringan lereng merupakan salah satu indikator syarat tumbuh tanaman tertentu. Begitu juga tanaman jeruk yang tidak dapat hidup pada kondisi kemiringan tertentu. Berikut kelas kemiringan lereng daerah penelitian yang disajikan pada Tabel 10.

Tabel 10. Kondisi Lereng di Kelurahan Pegagan Julu I Tahun 2017

\begin{tabular}{cccc}
\hline No & Lokasi Sampel & Kemiringan Lereng (\%) & Kriteria \\
\hline 1 & I & 4 & Datar \\
2 & II & 9 & Landai atau Berombak \\
3 & III & 18 & Agak Curam \\
4 & IV & 28 & Curam \\
5 & V & 43 & Sangat Curam \\
\hline
\end{tabular}

Berdasarkan Tabel 10 Kondisi kemiringan lereng di lokasi I memiliki kemiringan 4\% dengan kriteria Datar, pada lokasi II memiliki kemiringan 9\% dengan kriteria Landai atau Berombak, pada lokasi III memiliki kemiringan lereng 18\% dengan kriteria Agak Curam, pada lokasi IV memiliki kemiringan $28 \%$ dengan kriteria Curam dan pada lokasi $\mathrm{V}$ kemiringan lereng $43 \%$ dengan kriteria Sangat Curam.

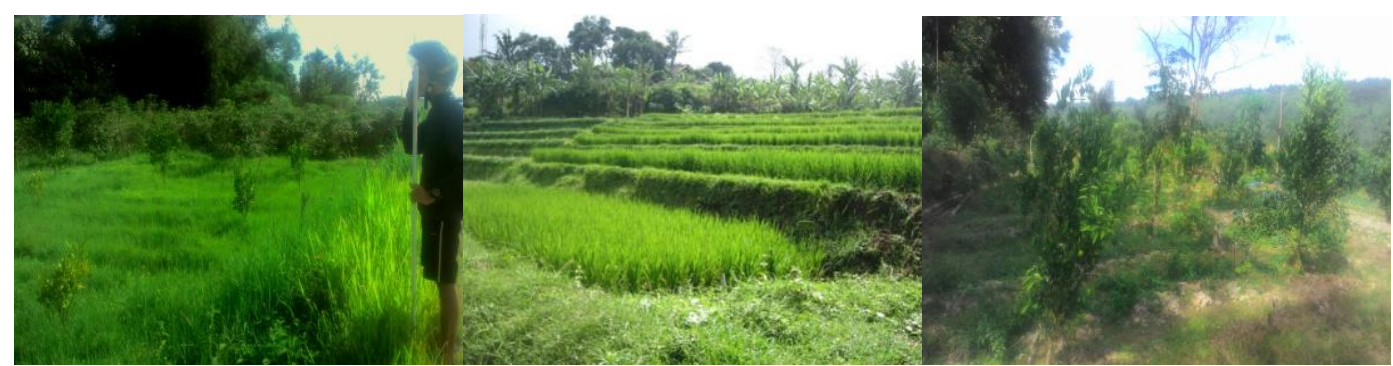

Gambar 2. Pengamatan kemiringan lereng

2) Singkapan Batuan

Batuan singkapan adalah batuan terungkap di atas permukaan tanah merupakan bagian dari batuan besar yang terbenam didalam tanah yang dapat muncul di permukaan akibat erosi pada tanah di atas dan sekitarnya sehingga batuan tersebut tersingkap. Singkapan batuan atau batuan tersingkap mempengaruhi pertumbuhan akar serta pengolahan lahan. Sama seperti batuan di permukaan, apabila terdapat batuan tersingkap dalam jumlah yang besar atau ukuran batu yang besar maka akan menghalangi pengolahan lahan dengan baik. Berikut hasil pengamatan mengenai kriteria singkapan batuan di 5 titik lokasi sampel penelitian yang disajikan pada Tabel 11 .

Tabel 11.Kriteria Singkapan Batuan pada lokasi penelitian di Kelurahan Pegagan Julu I Tahun 2017

\begin{tabular}{cccc}
\hline No & Lokasi Sampel & Kriteria (\%) & Luas Areal \\
\hline 1 & I & $>2$ & Tidak Ada \\
2 & II & $>2$ & Tidak Ada \\
3 & III & $>2$ & Tidak Ada \\
4 & IV & $>2$ & Tidak Ada \\
5 & V & $>2$ & Tidak Ada \\
\hline
\end{tabular}

Sumber: Hasil Pengamatan Lapangan, 2017 
Berdasarkan Tabel 11 menunjukkan bahwa kriteria singkapan batuan pada lokasi pengamatan I, II, III, IV dan V lebih kecil dari $2 \%$ yang artinya tidak terdapat singkapan batuan pada lokasi penelitian. Sehingga lokasi ini baik untuk ditanami tanaman jeruk dan tidak mengalami kesulitan dalam pengolahannya.

3) Batuan di Permukaan

Pertumbuhan dan perkembangan perakaran tanaman dipengaruhi oleh banyak tidaknya batuan di permukaan, semakin banyak batuan di permukaan maka semakin sulit akar tanaman dapat berkembang karena terhalang oleh batuan-batuan serta mengurangi kemampuan lahan untuk tanaman tertentu. Oleh sebab itu perlu dilakukan pengamatan mengenai keberadaan batuan di permukaan. Berikut hasil pengamatan mengenai keberadaan serta kriteria batuan di permukaan pada 5 titik lokasi pengamatan yang disajikan pada Tabel 12.

Tabel 12. Kriteria Batuan di permukaan pada lokasi penelitian di Kelurahan Pegagan Julu I Tahun 2017

\begin{tabular}{cccc}
\hline No & Lokasi Sampel & Kriteria (\%) & Luas Areal \\
\hline 1 & I & $<0,01$ & Tidak Ada \\
2 & II & $<0,01$ & Tidak Ada \\
3 & III & $<0,01$ & Tidak Ada \\
4 & IV & $<0,01$ & Tidak Ada \\
5 & V & $<0,01$ & Tidak Ada \\
\hline
\end{tabular}

Sumber: Hasil Pengamatan Lapangan, 2017

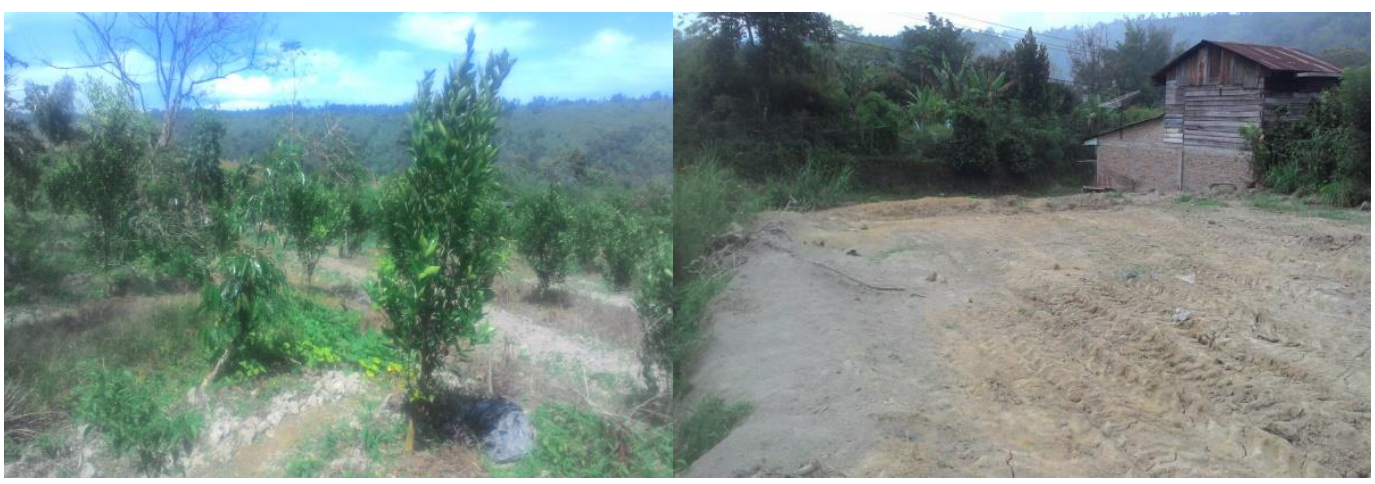

Gambar 3. Bentuk Permukaan Tanah

Gambar 3 menunjukkan bagaimana bentuk permukaan tanah di beberapa wilayah yang terdapat tanaman jeruk. Pada gambar tersebut terlihat bahwa tidak terdapatnya batuan permukaan dan singkapan batuan pada lahan.

\section{Kelas Kesesuaian Lahan untuk Tanaman Jeruk di Kelurahan Pegagan Julu 1 Berdasarkan hasil analisis laboratorium serta pengukuran dan pengamatan parameter di lapangan diperoleh data kelas kesesuaian lahan pada sebaran titik lokasi penelitian dan setiap titik lokasi}

mewakili lahan di Kelurahan Pegagan Julu I yang didasarkan pada tingkat kemiringan lereng yaitu Satuan lahan I, II, III, IV dan V.
a. Satuan Lahan I (0 - $8 \%)$
Berdasarkan Tabel 13 dapat diketahui bahwa Pada Satuan Lahan I kelas kesesuaiannya berada pada \$2 yaitu penggunaannya cukup sesuai untuk peruntukan saat ini, dengan pembatas yang ringan meliputi ketersediaan $\mathrm{N}$-Total, $\mathrm{P}_{2} \mathrm{O}_{5}$, KTK Liat dan Kedalaman tanah yang berada pada kelas $\$ 2$. 
Tabel 13. Karakteristik lahan satuan lahan I

\begin{tabular}{clcc}
\hline No & Karakteristik Lahan & Hasil Pengukuran/Lab & Kelas \\
\hline 1 & Temperatur & $21,50^{\circ}$ & $\mathrm{S} 1$ \\
2 & Curah Hujan & $1.794 \mathrm{~mm}$ & $\mathrm{~S} 1$ \\
3 & Drainase & $\mathrm{d} 1$ & $\mathrm{~S} 1$ \\
4 & Tekstur & Lempung Berpasir & $\mathrm{S} 1$ \\
5 & Kedalaman Tanah & $80 \mathrm{~cm}$ & $\mathrm{~S} 2$ \\
6 & $\mathrm{KTK}$ & $9,12 \mathrm{me} / 100 \mathrm{gr}$ & $\mathrm{S} 2$ \\
7 & $\mathrm{pH} \mathrm{H}_{2} \mathrm{O}$ & 5,67 & $\mathrm{~S} 1$ \\
8 & $\mathrm{~N}-\mathrm{T}_{\text {otal }}$ & $0,13 \%$ & $\mathrm{~S} 2$ \\
9 & $\mathrm{P}_{2}$ & $10,37 \mathrm{ppm}$ & $\mathrm{S} 2$ \\
10 & Kemiringan Lereng & $4 \%$ & $\mathrm{~S} 1$ \\
11 & Singkapan Batuan & $2 \%$ & $\mathrm{~S} 1$ \\
12 & Batuan di Permukaan & $2 \%$ & $\mathrm{~S} 1$ \\
\hline
\end{tabular}

Sumber: Analisis Data, 2017

b. Satuan Lahan I (8-15\%)

Berdasarkan Tabel 14 dapat diketahui bahwa Pada Satuan Lahan II kelas kesuamiannya berada pada \$2 yaitu penggunaan yang sesuai marginal untuk peruntukan saat ini. Faktor pembatas pada lahan ini yang cukup ringan adalah kedalaman tanah, KTK, N-Total, $\mathrm{P}_{2} \mathrm{O}_{5}$ dan Kemiringan lereng yang berada pada kelas $\$ 2$.

Tabel 14. Karakteristik lahan satuan lahan II

\begin{tabular}{clcc}
\hline No & Karateristik Lahan & Hasil Pengukuran/Lab & Kelas \\
\hline 1 & Temperatur & $21,5{ }^{\circ} \mathrm{C}$ & $\mathrm{S} 1$ \\
2 & Curah Hujan & $1.794 \mathrm{~mm}$ & $\mathrm{~S} 1$ \\
3 & Drainase & $\mathrm{d} 1$ & $\mathrm{~S} 1$ \\
4 & Tekstur & Lempung Berpasir & $\mathrm{S} 1$ \\
5 & Kedalaman Tanah & $78 \mathrm{~cm}$ & $\mathrm{~S} 2$ \\
6 & $\mathrm{KTK}$ & $11,34 \mathrm{me} / 100 \mathrm{gr}$ & $\mathrm{S} 2$ \\
7 & $\mathrm{pH} \mathrm{H} \mathrm{H}_{2} \mathrm{O}$ & 5,84 & $\mathrm{~S} 1$ \\
8 & $\mathrm{~N}-\mathrm{Total}$ & $0,15 \%$ & $\mathrm{~S} 2$ \\
9 & $\mathrm{P}_{2} \mathrm{O}_{5}$ & $12,10 \mathrm{ppm}$ & $\mathrm{S} 2$ \\
10 & Kemiringan Lereng & $9 \%$ & $\mathrm{~S} 2$ \\
11 & Singkapan Batuan & $2 \%$ & $\mathrm{~S} 1$ \\
12 & Batuan di Permukaan & $2 \%$ & $\mathrm{~S} 1$ \\
\hline
\end{tabular}

c. Satuan Lahan I (15-25\%)

Berdasarkan Tabel 15 dapat diketahui bahwa Pada Satuan Lahan III kelas kesesuaian lahannya berada pada $\$ 3$ yaitu penggunaan yang sesuai marginal untuk peruntukan saat ini. Faktor pembatas pada lahan ini yang cukup berat adalah Kemiringan lereng yang berada pada kelas S3, faktor pembatas lain yang ringan adalah Drainase, Kedalaman tanah, KTK, N-Total dan $\mathrm{P}_{2} \mathrm{O}_{5}$ yang berada pada kelas $\$ 2$.

Tabel 15. Karakteristik lahan satuan lahan III

\begin{tabular}{clcc}
\hline No & Karateristik Lahan & Hasil Pengukuran/Lab & Kelas \\
\hline 1 & Temperatur & $21,5{ }^{\circ} \mathrm{C}$ & $\mathrm{S} 1$ \\
2 & Curah Hujan & $1.794 \mathrm{~mm}$ & $\mathrm{~S} 1$ \\
3 & Drainase & $\mathrm{d} 3$ & $\mathrm{~S} 2$ \\
4 & Tekstur & Lempung Berpasir & $\mathrm{S} 1$ \\
5 & Kedalaman Tanah & $83 \mathrm{~cm}$ & $\mathrm{~S} 2$ \\
6 & $\mathrm{KTK}$ & $8,37 \mathrm{me} / 100 \mathrm{gr}$ & $\mathrm{S} 2$ \\
7 & $\mathrm{pH} \mathrm{H} \mathrm{H}_{2} \mathrm{O}$ & 6,12 & $\mathrm{~S}$ \\
8 & $\mathrm{~N}-\mathrm{T}_{2}$ & $0,15 \%$ & $\mathrm{~S} 2$ \\
9 & $\mathrm{P}_{2} \mathrm{O}_{5}$ & $10,54 \mathrm{ppm}$ & $\mathrm{S} 2$ \\
10 & Kemiringan Lereng & $18 \%$ & $\mathrm{S3}$ \\
11 & Singkapan Batuan & $2 \%$ & $\mathrm{S1}$ \\
12 & Batuan di Permukaan & $2 \%$ & $\mathrm{~S} 1$ \\
\hline
\end{tabular}


d. Satuan Lahan I (25-40 \%)

Berdasarkan Tabel 16 dapat diketahui bahwa Pada Satuan Lahan IV kelas kesesuaian lahannya juga berada pada kelas S3trf yaitu penggunaan yang sesuai marginal untuk peruntukan saat ini. Faktor pembatas pada lahan ini yang cukup berat adalah Kemiringan lereng yang berada pada kelas S3, faktor pembatas lain yang ringan adalah Drainase, Kedalaman tanah, KTK, N-Total dan $\mathrm{P}_{2} \mathrm{O}_{5}$ yang berada pada kelas $\$ 2$.

Tabel 16. Karakteristik lahan satuan lahan IV

\begin{tabular}{clcc}
\hline No & Karakteristik Lahan & Hasil Pengukuran/Lab & Kelas \\
\hline 1 & Temperatur & $21,5{ }^{\circ} \mathrm{C}$ & $\mathrm{S} 1$ \\
2 & Curah Hujan & $1.794 \mathrm{~mm}$ & $\mathrm{~S} 1$ \\
3 & Drainase & $\mathrm{d} 3$ & $\mathrm{~S} 2$ \\
4 & Tekstur & Lempung Berdebu & $\mathrm{S} 1$ \\
5 & Kedalaman Tanah & $87 \mathrm{~cm}$ & $\mathrm{~S} 2$ \\
6 & $\mathrm{KTK}$ & $10,29 \mathrm{me} / 100 \mathrm{gr}$ & $\mathrm{S} 2$ \\
7 & $\mathrm{pH} \mathrm{H} \mathrm{H}_{2} \mathrm{O}$ & 5,97 & $\mathrm{~S} 1$ \\
8 & $\mathrm{~N}-\mathrm{T}_{\text {otal }}$ & $0,14 \%$ & $\mathrm{~S} 2$ \\
9 & $\mathrm{P}_{2}$ & $13,09 \mathrm{ppm}$ & $\mathrm{S} 2$ \\
10 & Kemiringan Lereng & $28 \%$ & $\mathrm{S3}$ \\
11 & Singkapan Batuan & $2 \%$ & $\mathrm{~S} 1$ \\
12 & Batuan di Permukaan & $2 \%$ & $\mathrm{~S} 1$ \\
\hline
\end{tabular}

e. Satuan Lahan I (>40 \%)

Berdasarkan Tabel 17 dapat diketahui bahwa Pada Satuan Lahan $V$ kelas kesesuaian lahannya berada pada kelas $N$ yaitu penggunaannya berada pada kondisi Tidak Sesuai untuk peruntukan saat ini. Faktor Tabel 17. Karakteristik lahan satuan lahan V

\begin{tabular}{clcc}
\hline No & Karakteristik Lahan & Hasil Pengukuran/Lab & Kelas \\
\hline 1 & Temperatur & $21,5{ }^{\circ} \mathrm{C}$ & $\mathrm{S} 1$ \\
2 & Curah Hujan & $1.794 \mathrm{~mm}$ & $\mathrm{~S} 1$ \\
3 & Drainase & $\mathrm{D} 3$ & $\mathrm{~S} 2$ \\
4 & Tekstur & Lempung & $\mathrm{S} 1$ \\
5 & Kedalaman Tanah & $94 \mathrm{~cm}$ & $\mathrm{~S} 2$ \\
6 & $\mathrm{KTK}$ & $10.76 \mathrm{me} / 100 \mathrm{gr}$ & $\mathrm{S} 2$ \\
7 & $\mathrm{pH} \mathrm{H}_{2} \mathrm{O}$ & 5,76 & $\mathrm{~S} 1$ \\
8 & $\mathrm{~N}-$ Total & $0,09 \%$ & $\mathrm{S3}$ \\
9 & $\mathrm{P}_{2} \mathrm{O}_{5}$ & $10,24 \mathrm{ppm}$ & $\mathrm{S} 2$ \\
10 & Kemiringan Lereng & $43 \%$ & $\mathrm{~N}$ \\
11 & Singkapan Batuan & $2 \%$ & $\mathrm{~S} 1$ \\
12 & Batuan di Permukaan & $2 \%$ & $\mathrm{~S} 1$ \\
\hline
\end{tabular}

Sumber: Analisis Data, 2017

Berdasarkan Tabel 18 dapat diketahui bahwa, pada Satuan Lahan I kelas kesesuaiannya berada pada $\$ 2$ yaitu penggunaannya cukup sesuai untuk peruntukan saat ini, dengan pembatas yang ringan meliputi ketersediaan $\mathrm{N}$-Total, $\mathrm{P}_{2} \mathrm{O}_{5}$, KTK Liat dan Kedalaman tanah yang berada pada kelas S2. Pada Satuan Lahan II kelas kesesuaiannya berada pada S2 yaitu penggunaan yang sesuai marginal untuk peruntukan saat ini. Faktor pembatas pada lahan ini yang cukup ringan adalah kedalaman tanah, KTK, N-Total, $\mathrm{P}_{2} \mathrm{O}_{5}$ dan Kemiringan pembatas yang sangat berat pada lahan ini adalah Kemiringan lereng yang berada pada kelas N. Faktor pembatas lain yang ringan adalah kedalaman tanah $\mathrm{KTK}, \mathrm{P}_{2} \mathrm{O}_{5}$ dan $\mathrm{N}$ Total yang berada pada kelas $\mathrm{S} 2$. 
lahan ini yang cukup berat adalah Kemiringan lereng yang berada pada kelas S3, faktor pembatas lain yang ringan adalah Drainase, Kedalaman tanah, KTK, N-Total dan $\mathrm{P}_{2} \mathrm{O}_{5}$ yang berada pada kelas S2. Pada Satuan Lahan $\checkmark$ kelas kesesuaian lahannya berada pada kelas $\mathrm{N}$ yaitu penggunaannya berada pada kondisi
Tidak Sesuai untuk peruntukan saat ini. Faktor pembatas yang sangat berat pada lahan ini adalah Kemiringan lereng yang berada pada kelas N. Faktor pembatas lain yang ringan adalah kedalaman tanah $\mathrm{KTK}, \mathrm{P}_{2} \mathrm{O}_{5}$ dan $\mathrm{N}$ Total yang berada pada kelas $\$ 2$.

Tabel 18. Tingkat Kesesuaian Lahan untuk Tanaman Jeruk di Kelurahan Pegagan Julu I

\begin{tabular}{|c|c|c|c|c|c|c|}
\hline \multirow{2}{*}{ No } & \multirow{2}{*}{$\begin{array}{c}\text { Karakteristik Lahan } \\
\text { berdasarkan Kualitas Lahan }\end{array}$} & \multicolumn{5}{|c|}{ Lokasi } \\
\hline & & Lahan I & Lahan II & Lahan III & Lahan IV & Lahan V \\
\hline \multirow[t]{2}{*}{1} & Regim Temperatur ( $t$ ) & & & & & \\
\hline & - Suhu Rata-rata & S1 & S1 & $S 1$ & S1 & S1 \\
\hline \multirow[t]{2}{*}{2} & Ketersediaan Air (w) & & & & & \\
\hline & - Curah hujan tahunan & S1 & S1 & S1 & S1 & S1 \\
\hline \multirow[t]{4}{*}{3} & Media perakaran (f) & & & & & \\
\hline & - Drainase & S2 & S1 & \$2 & S2 & S1 \\
\hline & - Tekstur & S1 & S1 & S1 & S1 & S1 \\
\hline & - Kedalaman tanah & S2 & S2 & \$2 & S2 & S2 \\
\hline \multirow[t]{3}{*}{4} & Retensi hara (n) & & & & & \\
\hline & - KTK Liat & S2 & S2 & $\$ 2$ & S2 & S2 \\
\hline & - $\mathrm{pH} \mathrm{H} \mathrm{H}_{2} \mathrm{O}$ & S1 & S1 & S1 & S1 & S1 \\
\hline \multirow[t]{3}{*}{5} & Ketersediaan unsur hara $(r)$ & & & & & \\
\hline & - N-Total & S2 & S2 & $\$ 2$ & S2 & S3 \\
\hline & $-\mathrm{P}_{2} \mathrm{O}_{5}$ & \$2 & \$2 & $\$ 2$ & \$2 & S2 \\
\hline \multirow[t]{5}{*}{6} & Topografi (t) & & & & & \\
\hline & - Lereng & S1 & S2 & S3 & S3 & $\mathrm{N}$ \\
\hline & - Batuan Permukaan & S1 & S1 & S1 & S1 & S1 \\
\hline & - Singkapan Batuan & S1 & S1 & S1 & S1 & S1 \\
\hline & Kelas Kesesuaian Lahan & S2fr & $S 2 r$ & S3fr & S3trf & Ntr \\
\hline
\end{tabular}

\section{KESIMPULAN}

1. Karakteristik lahan di Kelurahan Pegagan Julu I cukup baik untuk peruntukan tanaman jeruk. Hal ini didukung oleh rata-rata suhu harian sebesar 21,50C dan curah hujan tahunan sebesar $1.794 \mathrm{~mm} /$ tahun yang baik untuk tanaman jeruk. Beberapa karakteristik lahan yang lain juga mendukung tumbuhnya tanaman jeruk karena memiliki drainase yang agak baik, tekstur lempung berpasir, kedalaman tanah yang dalam sekitar 78-94 cm, KTK liat yang cukup sebesar 8,37-11,34, pH H2O yang normal antara 5,67-6,12, P2O5 sebesar 10,24-13,09 ppm dan tidak terdapatnya batuan di permukaan serta singkapan batuan. Beberapa karakteristik yang menghambat tumbuhnya tanaman jeruk ialah ketersediaan $\mathrm{N}$-Total yang rendah dan kemiringan lereng yang terjal dengan persentase sebesar $2 \%$ dari keseluruhan lahan di kelurahan tersebut.

2. Kelurahan Pegagan Julu I berada pada kelas kesesuaian lahan S2sr. Lahan yang memiliki pembatas paling banyak adalah satuan lahan IV dan $V$ dengan persentase luasan lahan sebesar $5 \%$ dari keseluruhan lahan dan faktor pembatasnya ialah ketersediaan N-Total yang berada pada kelas S3 dan Kemiringan lereng yang berada pada kelas N. Sedangkan lahan yang memiliki pembatas paling sedikit adalah satuan lahan I, II dan III dengan persentase luas sebesar 95\% dari keseluruhan lahan. Faktor pembatas ringan pada satuan lahan ini yaitu KTK, N-Total, P2O5 dan kemiringan lereng yang masing berada pada kelas $\mathbf{2}$. Drainase, tekstur, pH, batuan permukaan dan singkapan batuan menjadi faktor pendukung di satuan lahan ini karena masing-masing berada pada kelas $S 1$. 


\section{DAFTAR PUSTAKA}

Badan Pusat Statistik. (2014). Indonesia Dalam Angka 2014. BPS. Jakarta.

Fauzi. 2012. Budidaya Tanaman Jeruk. Malang. Penerbit Andi

Hanafiah. Kemas Ali. 2005. Dasar-dasar Ilmu Tanah. Jakarta: Raja Grafindo Persada.

Jamulya dkk. 1991. Evaluasi Sumber Daya Lahan untuk Pertanian. untuk Pertanian. Yogyakarta: Fakultas Geografi UGM.

Kartasapoetra, dkk. 1985. Teknologi Konservasi Tanah dan Air. Jakarta: Penerbit Rineka Cipta.

Kartasapoetra. 1988. Teknologi Budidaya Tanaman Pangan di Daerah Tropik. Jakarta: Bina aksara.

Kartosapoetra, Ance Gunarsih.1986. Klimatologi Pengaruh Iklim Terhadap Tanah dan Tanaman. Jakarta: Bina Aksara.

Kelurahan Pagagang Julu I, 2015. Data Mnografi Kelurahan. Tidak dipublikasi.

Munawar, ali. 2011. Kesuburan Tanah dan Nutrisi Tanaman. Bogor: IPB Press

Rayes, luthfi. 2006. Metode Inventarisasi Sumber Daya Lahan. Yogyakarta: Penerbit Andi.

Sartohadi, junun, dkk. 2012. Pengantar Geografi Tanah. Yogyakarta: Pustaka Pelajar.

Sianturi, D., \& Simanungkalit, N. M. (2017). Analisis Kelas Kesesuaian Lahan Untuk Tanaman Bawang Merah di Desa Pasaran Parsaoran Kecamatan Nainggolan Kabupaten Samosir. JURNAL GEOGRAFI, 9(2), 141-150.

Simarmata, Monang. 2015. Analisis Kesesuaian Lahan Perkebunan Jeruk di Desa Pegagan Julu VII Kecamatan Sumbul Kabupaten Dairi. Skripsi (tidak diterbitkan). Medan: Fakultas IImu Sosial Universitas Negeri Medan

Siswanto. 2006. Evaluasi Sumber Daya Lahan. Surabaya: Penerbit UPN Press. 
available at http://jurnal.unimed.ac.id/2012/index.php/tgeo

Jurnal Tunas Geografi

e-ISSN: 2622-9528 p-ISSN: 2301-606X

Vol 07 No. $01-2018$ 